\title{
SENSITIVE DETERMINATION OF 3,4-DIHYDROXY-L-PHENYLALANINE BY A CLOUD FUNNEL MUSHROOM (Clitocybe nebularis (Batsch), P. Kumm.) HOMOGENATE-BASED AMPEROMETRIC BIOSENSOR
}

\author{
Engin ASAV \\ Kırklareli Univesity, Faculty of Health Sciences, Nutrition and Dietetics Department, Kurklareli, TURKEY \\ engin.asav@klu.edu.tr ORCID: 0000-0002-6232-3388
}

Cite this article as:

Asav E. 2021. Sensitive determination of 3,4-dihydroxy-1-phenylalanine by a cloud funnel mushroom (Clitocybe nebularis (Batsch), P. Kumm.) homogenate-based amperometric biosensor. Trakya Univ J Nat Sci, 22(2): 263-274, DOI: 10.23902/trkjnat.969982

Edited by:

Özkan Danlş

Key words:

Clitocybe nebularis

$L-D O P A$

Carbon-paste electrode

Tissue homogenate

Electrochemistry

\begin{abstract}
L-phenylalanine (L-DOPA) is one of the precursor molecules for the biosynthesis of neurotransmitters in the brain. Monitoring of L-DOPA levels as a drug or biomolecule in biological fluids is crucial for the treatment of patients suffering from Parkinson's Disease. This study aimed to construct a cloud funnel mushroom (Clitocybe nebularis (Batsch), P. Kumm.) tissue homogenate-based biosensor for precise and sensitive detection of L-DOPA in artificial plasma and urine. For this purpose, in the fabrication of the biosensor, tissue homogenate of $C$. nebularis was immobilized into a carbon paste electrode by using graphite, mineral oil, gelatine and glutaraldehyde. The amperometric signals corresponding to $600 \mathrm{~s}$ were recorded as response current for each L-DOPA concentration. All amperometric measurements were carried out at $-700 \mathrm{mV}$ (versus $\mathrm{Ag} \mid \mathrm{AgCl}$ ). The present biosensor successfully detected L-DOPA with a linear dynamic range at $2.5-100 \mu \mathrm{M}$ and Limit of Detection (LOD) value as $0.76 \mu \mathrm{M}$, as well as standard deviation as $\pm 0.41 \mu \mathrm{M}$ and coefficient of variation as $0.82 \%(n=16)$. Additionally, the determination of L-DOPA spiked in artificial plasma and urine was carried out successfully. The present work would be the first study that utilized $C$. nebularis tissue as a biosensor component.
\end{abstract}

Özet: 3,4-dihidroksifenilalanin (L-DOPA), beyinde nörotransmitter sentezi için öncül moleküllerden biridir. Biyolojik sıvılarda, ilaç veya biyomolekül olarak L-DOPA düzeylerinin izlenmesi, Parkinson hastalı̆̆ına sahip kişilerin tedavi süreci için önemlidir. Bu çalışmanın amacı, sentetik plazma ve idrar örneklerinde L-DOPA molekülünün doğru ve duyarlı bir tayinine yönelik, bulutlu huni mantarı (Clitocybe nebularis (Batsch), P. Kumm.) doku homejenatı temelli bir biyosensör sistemi geliştirmektir. Bu bağlamda, biyosensör yapımında, C. nebularis doku homojenatı; grafit, mineral yağ, jelatin ve glutaraldehit kullanılarak karbon pasta elektrot içine immobilize edilmişlerdir. 600. saniyeye karşılık gelen amperometrik sinyaller her L-DOPA konsantrasyonu için yanıt akımı olarak kaydedilmiştir. Tüm amperometrik ölçümler $-700 \mathrm{mV}$ (vs $\mathrm{Ag} \mid \mathrm{AgCl})$ potansiyelinde gerçekleştirilmiştir. Geliştirilen biyosensör, L-DOPA molekülünü 2,5-100 $\mu \mathrm{M}$ tayin aralığında ve 0,76 $\mu \mathrm{M}$ tayin limitinin yanı sira $\pm 0,41 \mu \mathrm{M}$ standart sapma $(\mathrm{n}=16)$. ve $\% 0,82$ varyasyon katsayıs 1 ile saptayabilmiştir. Ayrıca sentetik plazma ve idrar içerisine eklenmiş L-DOPA miktarının da tayini başarı ile gerçekleştirilmiştir. Bu çalışma $C$. nebularis dokusunun ilk kez bir biyosensör bileşeni olarak kullanıldığı çalışmadır.

\section{Introduction}

In the last two decades, the field of electrochemical biosensors has evolved rapidly by means of various types of transducers including amperometric (Ozcan \& Aydin 2016), potentiometric (Rasmussen et al. 2007), and voltammetric (Li et al. 2015) along with bio-components such as tissues (Ozcan \& Sagiroglu 2014), enzymes (Davletshina et al. 2020), antibodies (Sayikli Şimşek et al. 2015), microorganisms (Gao et al. 2017) and DNA (Faria
\& Zucolotto 2019). Electrochemical biosensors offer various advantages over conventional analytical techniques including sensitivity, precision, low cost and portability as well as simplicity of the instrumentation and fast response time (da Silva et al. 2017). Hence, biosensor systems are widely used for the detection of several target molecules in the fields of medical diagnosis (Sun et al. 2014), bioprocess control (Pontius et al. 2020), 
environmental analyses (Nomngongo et al. 2011), food quality control (Sagiroglu et al. 2011) and pharmaceutical analyses (Camargo et al. 2020).

In the construction of tissue-based electrochemical biosensors, tissue homogenates from various living organisms such as pigs (Thoppe Rajendran et al. 2020), mushrooms (Sezgintürk \& Dinçkaya 2012) and plant tissues including banana (Ozcan \& Sagiroglu 2010), artichoke (Odaci et al. 2004), Myrtle (Ayna \& Akyilmaz 2018) are employed for detection of toxins (Sanders et al. 2001), drugs (Thoppe Rajendran et al. 2020), herbicides (Breton et al. 2006) and phenolic compounds such as rutin (Zwirtes de Oliveira et al. 2006), epinephrine (Felix et al. 2006), caffeic acid (Fernandes et al. 2007), catechol (Ozcan \& Sagiroglu 2010) and dopamine (Ori et al. 2014).

Clitocybe nebularis (Batsch), P. Kumm. known as clouded agaric or cloud funnel mushroom is a wellstudied fungus, thanks to the neuroprotective, antioxidant, antimicrobial and cytotoxic properties of its constituents (Kosanić et al. 2020). Although C. nebularis was reported to have laccase gene (Luis et al. 2004), neither determination of laccase activity nor utilization in biosensor construction have not been studied so far.

3,4-dihydroxy-L-phenylalanine (L-DOPA) has great importance for neurobiochemical reactions in the brain since it is a precursor for catecholamines including dopamine, epinephrine and norepinephrine. Due to the ability to pass the blood-brain barrier, L-DOPA specimens are effective drugs for the treatment of Parkinson's Disease (Hormozi-Nezhad et al. 2017). In the last two decades, several analytical methods such as HPLC (Kumarathasan \& Vincent 2003), LC/MS (César et al. 2011), spectrophotometric (Tashkhourian et al. 2011), electrochemical (Brunetti et al. 2014), colorimetric (Chou et al. 2019) were developed for the detection of L-DOPA, owing to the pharmacological importance of L-DOPA. Amperometry is one of the widely used electrochemical methods in tissue-based biosensors as well as in determination of L-DOPA, since it is easy to apply, inexpensive and allows simultaneous monitoring of responses (Brunetti et al. 2014, Sandeep et al. 2018, Timur et al. 2004).

The aim of our study was the development of a simply constructed $C$. nebularis tissue homogenate-based biosensor, which could detect accurately and sensitively L-DOPA in artificial plasma and urine. Therewithal, the determination of laccase activity of $C$. nebularis by using the ABTS method would be accomplished for the first time.

\section{Materials and Methods}

\section{Materials and Reagents}

Graphite, mineral oil, 3,4-dihydroxy-L-phenylalanine (L-DOPA), 2,2'-azinobis[3-ethylbenzothiazoline-6sulfonic acid], diammonium salt (ABTS), bovine serum albumin (BSA) and all other chemicals were purchased from Sigma-Aldrich (St. Louis, MO, USA). In all experiments, measurements and preparation of the solutions, except ABTS prepared in $100 \mathrm{mM}$ citrate buffer at $\mathrm{pH} 4.0$, were carried out in $50 \mathrm{mM}$ phosphate buffer at $\mathrm{pH}$ 7.0. The cloud funnel mushroom was collected from Istranca Mountains (Kırklareli-Turkey) in November 2019 and stored at $-80^{\circ} \mathrm{C}$ until use. The commercial drug specimens of L-DOPA named Madopar ${ }^{\circledR}$ containing 100 mg L-DOPA and Dopalevo ${ }^{\circledR}$ containing $100 \mathrm{mg}$ L-DOPA were purchased from a local pharmacy. The artificial serum solution was prepared in a $50 \mathrm{mM}$ phosphate buffer system at $\mathrm{pH} 7.5$ by adding $2.5 \mathrm{mM}$ urea, $0.1 \%$ human serum albumin and $4.7 \mathrm{mM}(\mathrm{D}+)$-glucose as well as serum electrolytes including $4.5 \mathrm{mM} \mathrm{KCl}, 5 \mathrm{mM} \mathrm{CaCl}_{2}$, $145 \mathrm{mM} \mathrm{NaCl}$. The artificial serum solution was used without any dilution. Artificial human urine was prepared in a $50 \mathrm{mM}$ phosphate buffer system at $\mathrm{pH} 6.5$ by addition of $1.49 \mathrm{mM}$ uric acid, $2.45 \mathrm{mM}$ sodium citrate, $7.79 \mathrm{mM}$ creatinine, $249.75 \mathrm{mM}$ urea, $0.19 \mathrm{mM}$ potassium oxalate, $23.67 \mathrm{mM}$ ammonium chloride along with $11.97 \mathrm{mM}$ $\mathrm{Na}_{2} \mathrm{SO}_{4}, 4.39 \mathrm{mM} \mathrm{MgSO} 4,1.66 \mathrm{mM} \mathrm{CaCl}_{2}, 30.95 \mathrm{mM}$ $\mathrm{KCl}$ and $30.05 \mathrm{mM} \mathrm{NaCl}$. This method was described in detail by Sarigul et al. (2019).

\section{$\underline{\text { Apparatus }}$}

All electrodes of the three-electrode system including a carbon-paste working electrode, $\mathrm{Pt}$ wire as counter electrode and $\mathrm{Ag} / \mathrm{AgCl}$ as reference electrode were purchased from $\mathrm{BASi}^{\circledR}$ Corporate (Indiana, USA). $\mathrm{Ag} / \mathrm{AgCl}$ reference electrode was stored in $3 \mathrm{M} \mathrm{KCl}$ solution for saturation until usage. A PC-controlled potentiostat, PalmSens $3{ }^{\circledR}$, along with PSTrace ${ }^{\circledR}$ software, which was used in all electrochemical experiments were purchased from PalmSens BV (Utrecht, Netherlands). A Potter-Elvehjem homogenizer purchased from İnterlab (İstanbul, Turkey) was used for homogenization of the mushrooms. A spectrophotometer purchased from ThermoFisher Scientific (Renfrewshire, UK) was used for protein and activity assays. A circulating thermostat named BM302 employed for thermostable conditions in all experiments was purchased from Nüve (Ankara, Turkey).

Determination of Biochemical Properties of Clitocybe nebularis

The isolation of laccase from C. nebularis was carried out by the modification of the method described before (Zhang et al. 2010, Tuncay \& Yagar 2020). For this purpose, washed and dried mushrooms were homogenized by using a Potter-Elvehjem homogenizer containing $0.15 \mathrm{M} \mathrm{NaCl}$. Then, the homogenate was centrifuged at $8000 \mathrm{rpm}$ for $15 \mathrm{~min}$. The resultant supernatant was used as the enzyme source for spectrophotometric measurements.

Protein assays via BSA and Coomassie Brilliant Blue G-250 were carried out according to the Standard Bradford method (Bradford 1976) for determination of the protein amounts of $C$. nebularis tissue homogenates.

A modified version of the ABTS method described by Shin \& Lee (2000) was used for determination of laccase activity of tissue homogenates. The absorbance values at $420 \mathrm{~nm}$ and $25^{\circ} \mathrm{C}$ of the assay mixture containing tissue homogenates $(0.1 \mathrm{~mL})$ and $\operatorname{ABTS}(0.9 \mathrm{~mL})$ were 
monitored for 3 minutes. The data from the measurements that occurred at time intervals of $0,30,60,90,120,180$ and $240 \mathrm{~s}$ were recorded for calculation of activity. One unit of enzyme activity was defined as the amount of enzyme required to oxidize $1 \mu \mathrm{mol}$ of ABTS per min. The laccase activity of $C$. nebularis tissue homogenates was calculated according to the equitation of the study of Baltierra-Trejo et al. (2015). The laccase activity equitation was given below where,

\section{$\Delta \mathrm{A}$ : Final absorbance - initial absorbance}

Vt: total volume $(\mathrm{mL})$

Vs: volume of tissue homogenates $(\mathrm{mL})$

$\varepsilon$ : coefficient of molar extinction of $\operatorname{ABTS}(36,000 \mathrm{~L}$ $\mathrm{mol}^{-1} \mathrm{~cm}^{-1}$ at $420 \mathrm{~nm}$ )

$$
\text { Laccase activity }\left(U L^{-1}\right)=\frac{\Delta A \times V t(m L) \times 10^{6}}{\varepsilon \times V S(m L) \times t(\min .)}
$$

\section{The Biosensor Construction}

Prior to use, the carbon paste electrode was sonicated in absolute ethanol to remove physically absorbed particles in the cavity of the electrode. The construction of the biosensor was carried out by the modification of the method described before (Kozan et al. 2007). For this purpose, $120 \mathrm{mg}$ of graphite powder and $140 \mu \mathrm{L}(60 \mathrm{mg})$ of mineral oil were mixed for 10 minutes to obtain a homogenous carbon paste. Subsequently, $30 \mu \mathrm{L}$ aliquot of C. nebularis tissue homogenate, which was obtained by using a Potter-Elvehjem homogenizer containing $0.15 \mathrm{M}$ $\mathrm{NaCl}$, were strewed thoroughly into carbon paste by mixing the slurry. Then, the tissue homogenate modified carbon paste was carefully and firmly packed into the cavity of the electrode. After the electrode surface was smoothed with a weighing paper, $25 \mu \mathrm{L}$ of gelatine at 2.5 $\mathrm{mg} / \mathrm{mL}$ concentration was dropped and dispersed onto the modified electrode as a protective layer. After the incubation of the gelatine-modified electrode at $+4^{\circ} \mathrm{C}$ for 30 minutes, the electrode was dipped in the $2.5 \%$ glutaraldehyde solution as a cross-linker prepared in 0.1 M PBS at pH 7.5. Finally, for a well-built cross-linking, the electrode was allowed to incubate for 15 minutes in this solution. Then, the biosensor was rinsed carefully with distilled water. The construction of the $C$. nebularis tissue homogenate-based biosensor was schematically shown in Fig. 1.

\section{The Principle of the Measurements}

The principle of the measurements was based on monitoring the amperometric responses of the biosensor for the oxidation of L-DOPA to dopaquinone by $C$. nebularis tissue. The amperometric signals were measured by using the three-electrode system at a constant temperature $\left(35^{\circ} \mathrm{C}\right)$ and in $20 \mathrm{~mL}$ of $50.0 \mathrm{mM}$ PBS at $\mathrm{pH} 7.5$ under the operating potential of $-700 \mathrm{mV}$ (versus $\mathrm{Ag} \mid \mathrm{AgCl}$ ), which was the reduction potential of oxygen (Ozcan \& Sagiroglu 2014). For each measurement, the electrode was allowed to equilibrate for $100 \mathrm{~s}$ to the signal to reach a steady-state that was recorded as the baseline current.

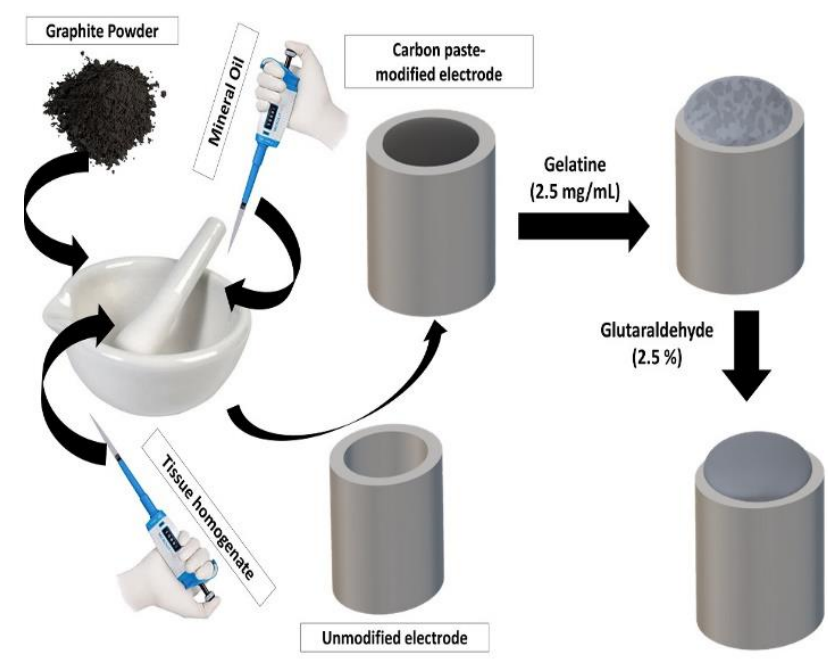

Fig. 1. Schematic presentation of construction of tissue homogenate-based biosensor.

The amperometric signals corresponding to $600 \mathrm{~s}$ were recorded as response current for each L-DOPA concentration, which was added separately in a freshened electrolyte solution. The differences between the baseline current values and response current values were calculated and denoted as $\Delta \mathrm{I}$. After each measurement, the electrode was allowed to regenerate in PBS for $3 \mathrm{~min}$.

\section{Analyses in Artificial Plasma and Urine}

Artificial plasma and urine were prepared as described above. Both of these solutions were used as an electrolyte solution instead of PBS in the measurement cell. Moreover, L-DOPA and commercial drugs named Madopar ${ }^{\circledR}$ and Dopalevo ${ }^{\circledR}$ were spiked in these solutions separately for evaluations of the analytical performance of the proposed biosensor. Tablets of each commercial drug were dissolved in $10 \mathrm{~mL} \mathrm{PBS}$ at $\mathrm{pH} 7.5$ by incubating in a sonicating bath for $30 \mathrm{~min}$. Then, the drug samples were filtered and centrifuged at $6000 \mathrm{rpm}$ for $10 \mathrm{~min}$ to obtain a bright and homogenous drug solution. The spectrophotometric method for the detection of L-DOPA was based on the measurement of absorbance levels at 280 nm (Karpińska et al. 2005). An L-DOPA calibration curve with a dynamic range of 10-200 $\mu \mathrm{M}$ was plotted for each reaction medium including $\mathrm{PBS}$, artificial plasma and urine. In case the absorbance was higher than the detection range, a dilution was applied to drug solutions. Furthermore, for drug analyses, another L-DOPA calibration curve with a linear range of $10-200 \mu \mathrm{M}$ was plotted by using the present tissue homogenate-based biosensor. Concentrations of the drug solutions were not properly calculated, owing to the dissociation problem of the drug tablets. Thus, a spectrophotometric method was employed to determine the exact concentration of the drug solutions. Hence, in biosensor experiments, drug solutions were diluted with PBS, artificial plasma or urine by evaluating the concentrations detected via spectrophotometry. Then, the L-DOPA levels of drug solutions were determined for comparison with the present biosensor. 


\section{Statistical Analysis}

The Limit of Detection (LOD) representing the lowest detected quantity of L-DOPA biosensor was determined via the equation of $3.3 \times S d / m$. Sd and $m$ which represent the standard deviation of the intercepts and slope of the calibration curve, respectively, were calculated by using the regression module of Microsoft Excel $^{\circledR}$ software. For evaluation of the repeatability of the parameters, $\Delta \mathrm{I}$ values measured for 16 separate addition of L-DOPA at $50.0 \mu \mathrm{M}$ were replaced as " $\mathrm{y}$ " in the equation of calibration curve.

The mean values, standard deviations and coefficients of variation of the biosensor were calculated by using Microsoft Excel ${ }^{\circledR}$ software.

\section{Results}

\section{Biochemical Properties of Clitocybe nebularis}

In total protein assay via the standard method of Bradford, the protein concentration of $C$. nebularis was determined as $0.421 \mathrm{mg} / \mathrm{mL}$. The laccase activity determined via the ABTS method was calculated as 144.54 U/L according to the equation given above.

\section{Optimization of the Biosensor Fabrication}

Optimization experiments of the immobilization steps had great importance to evaluate effective detection characteristics for the biosensor constructed. For this purpose, parameters including the amount of gelatine, the amount of mushroom tissue and the volume of homogenate as well as $\mathrm{pH}$ and temperature were optimized.

The concentration of gelatin directly affected the signal rate, since gelatine acted as a slight barrier for oxygen and L-DOPA transport. However, the protection and stability of the electrode surface were provided by the gelatine layer. Thus, the optimization of the concentration of gelatine was one of the crucial steps for biosensor construction. For the determination of optimum gelatine amount, four different electrodes were fabricated by using gelatine at different concentrations as $1.0 \mathrm{mg} / \mathrm{mL}, 2.5$ $\mathrm{mg} / \mathrm{mL}, 5 \mathrm{mg} / \mathrm{mL}$ and $10 \mathrm{mg} / \mathrm{mL}$. Calibration curves shown in Fig. 2 for each concentration of gelatine were plotted between $\triangle \mathrm{I}$ values and L-DOPA concentrations.

The amount of mushroom tissue for the preparation of tissue homogenate was an important parameter for the catalytic reaction of L-DOPA and indirectly the signal rate. Hence, tissue homogenates coalesced with carbon paste were prepared by using different amounts of $C$. nebularis tissue including $50 \mathrm{mg}, 100 \mathrm{mg}, 200 \mathrm{mg}$ and $400 \mathrm{mg}$. Calibration curves for each amount of $C$. nebularis tissue plotted between $\Delta \mathrm{I}$ values and L-DOPA concentrations were shown in Fig. 3.

Determination of the optimum volume of tissue homogenate coalescing to carbon paste is a critical step to obtain a homogenous dispersion of tissue in the carbon paste stuffing the electrode cavity. For this purpose, three different carbon pastes consisted of tissue homogenate at different volumes including $15 \mu \mathrm{L}, 30 \mu \mathrm{L}$ and $60 \mu \mathrm{L}$ were prepared and used for biosensor construction. Calibration curves obtained from these biosensors are shown in Fig. 4.

For the determination of optimum $\mathrm{pH}$ of the tissue homogenate-based biosensor, different buffer systems including citrate buffer for $\mathrm{pH}$ values between 4.5 and 5.5 along with phosphate buffer for $\mathrm{pH}$ values between 6.0 and 8.0 were prepared and used in the reaction cell. The measurements and regenerations were carried out separately in these seven buffer systems by using the same biosensor. In the optimum $\mathrm{pH}$ experiments, signal levels corresponding to L-DOPA at $5 \mu \mathrm{M}$ concentrations for each buffer system were monitored and recorded. Relative activity calculated by using biosensor responses at different $\mathrm{pH}$ levels is shown in Fig. 5.

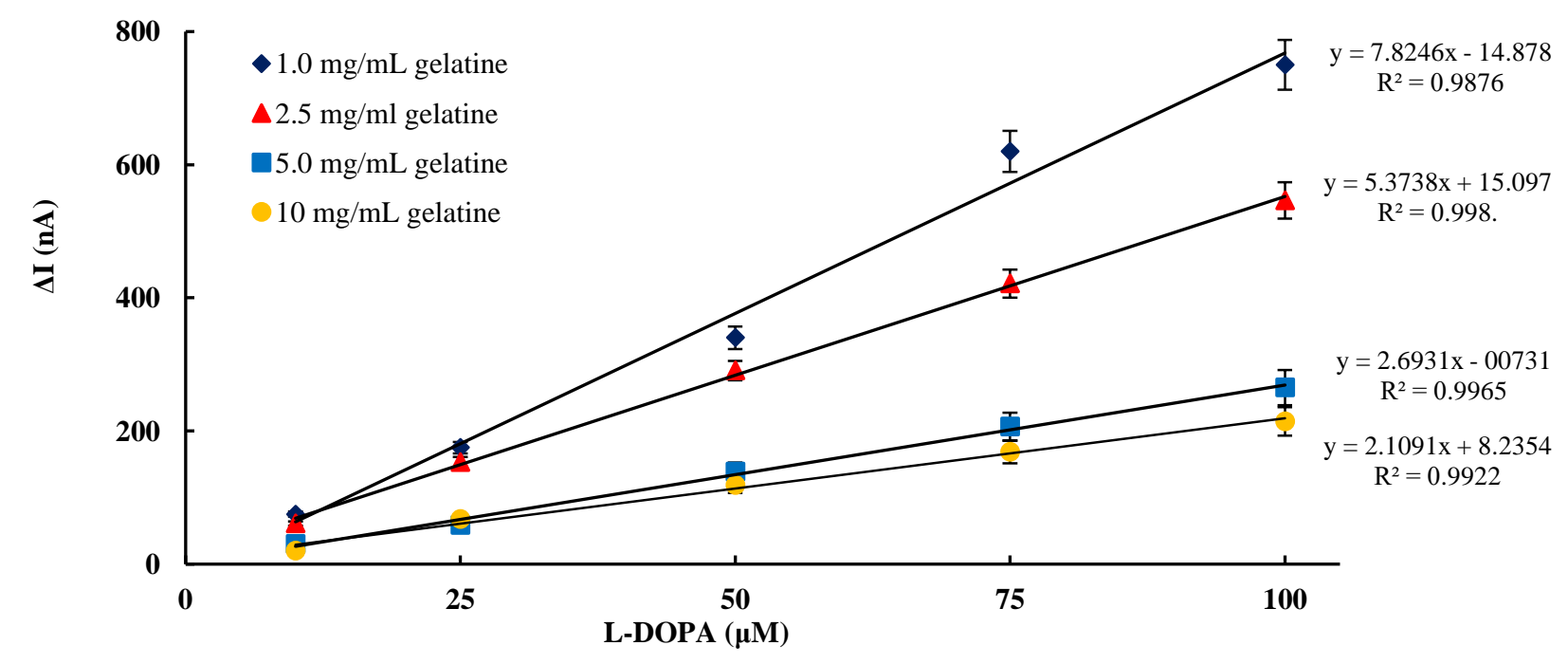

Fig. 2. Calibration curves obtained from the biosensors contained different concentrations of gelatine dissolved in PBS. 


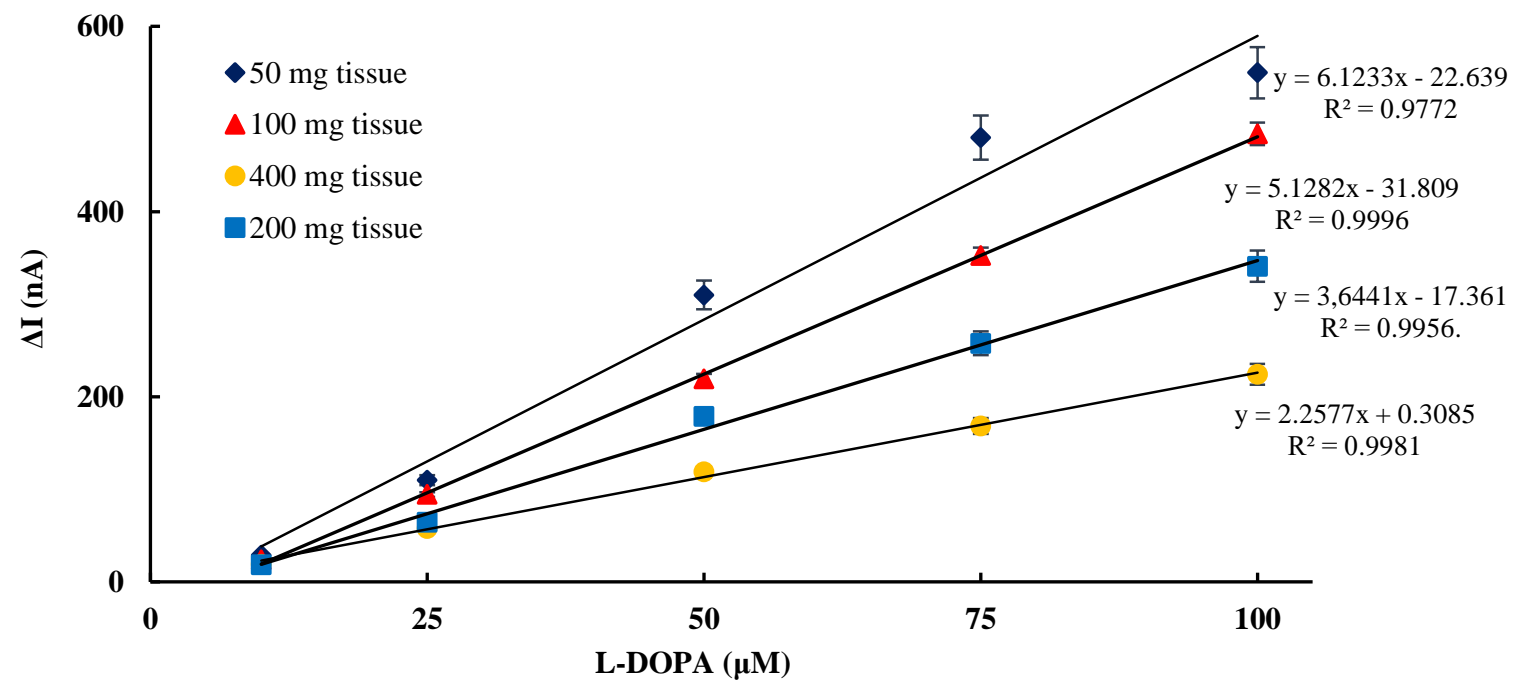

Fig. 3. Calibration curves were obtained from the biosensors prepared with different amounts of C. nebularis tissue.

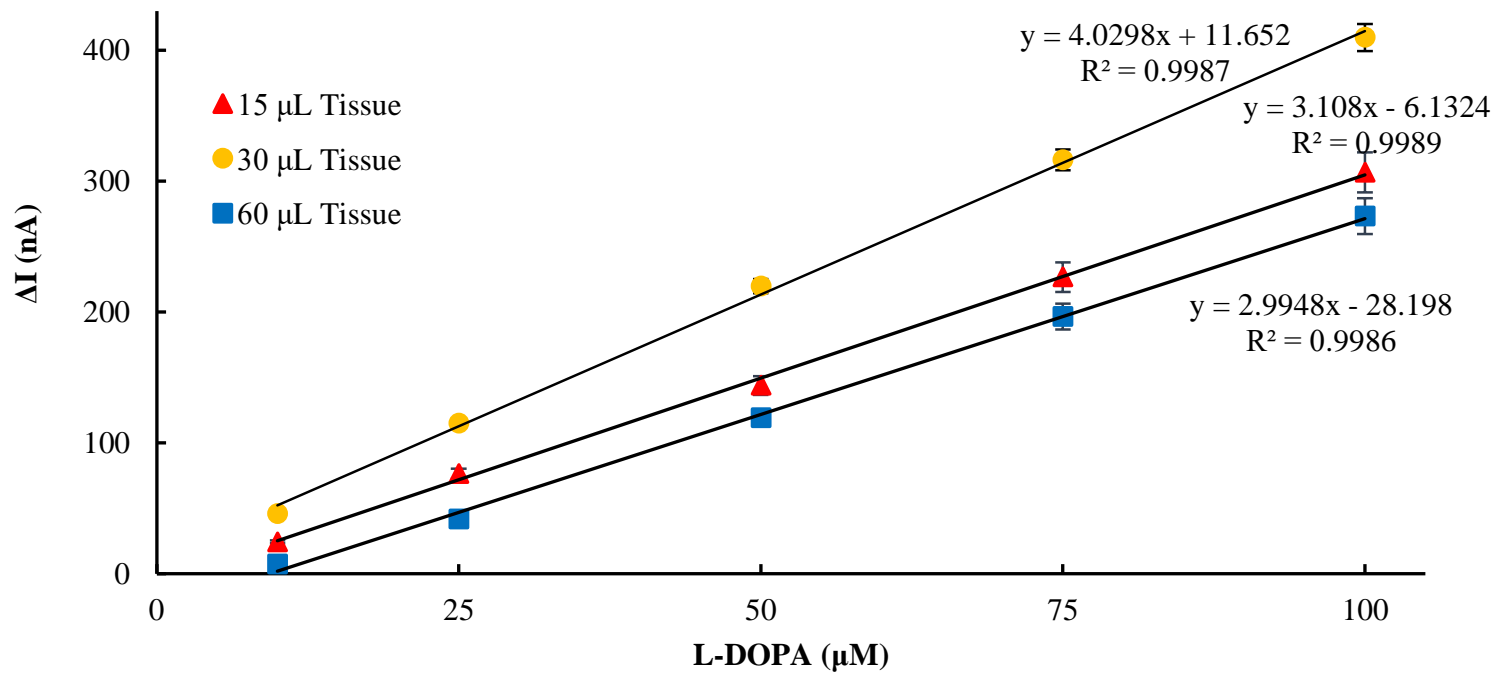

Fig. 4. Calibration curves obtained from the biosensors contained different volumes of tissue homogenate.

For the determination of optimum temperature, the measurements and regenerations were carried out in different temperature conditions including $15^{\circ} \mathrm{C}, 20^{\circ} \mathrm{C}$, $25^{\circ} \mathrm{C}, 30^{\circ} \mathrm{C}, 35^{\circ} \mathrm{C}, 40^{\circ} \mathrm{C}$ and $45^{\circ} \mathrm{C}$. In the optimum temperature experiments, biosensor responses corresponding to L-DOPA at $5 \mu \mathrm{M}$ concentrations for each degree were monitored and recorded. Relative activity calculated by using biosensor responses at different temperatures is shown in Fig. 6.

\section{Linear range}

For the determination of linear range, the limit of detection (LOD) and sensitivity of the present biosensor, a biosensor was fabricated by using optimum conditions determined before. Then, a calibration curve shown in Fig. 7 was plotted between $\Delta \mathrm{I}$ values and L-DOPA concentrations at $2.5 \mu \mathrm{M}, 5.0 \mu \mathrm{M}, 10 \mu \mathrm{M}, 25 \mu \mathrm{M}, 50 \mu \mathrm{M}$, $75 \mu \mathrm{M}$ and $100 \mu \mathrm{M}$.

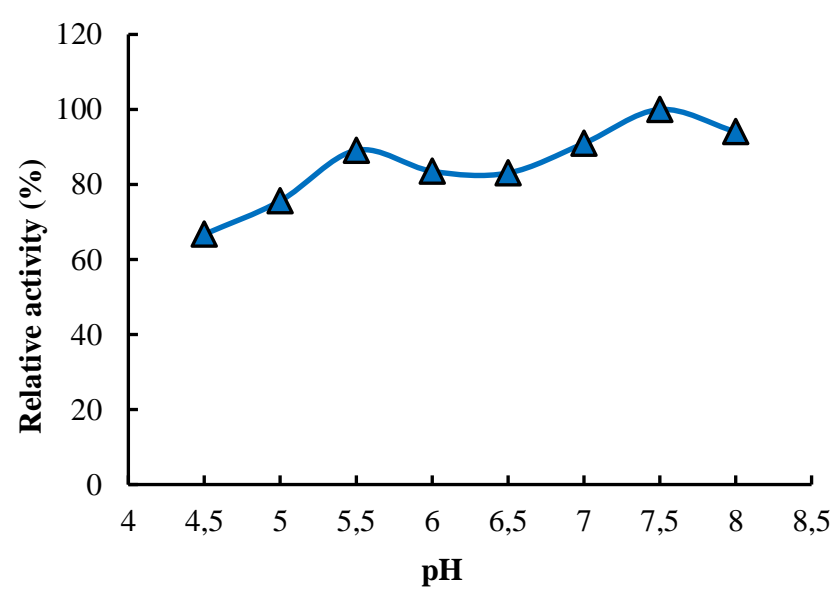

Fig. 5. The effect of $\mathrm{pH}$ on biosensor responses. 


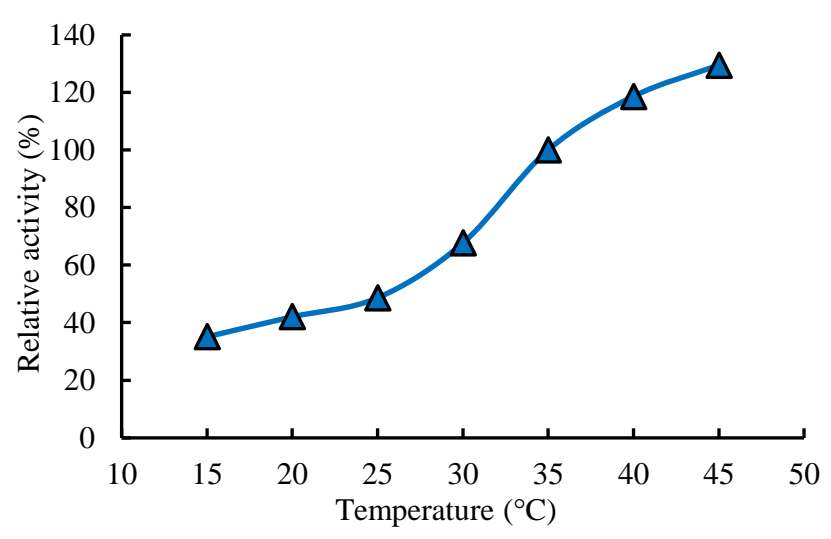

Fig. 6. The effect of temperature on the biosensor responses.

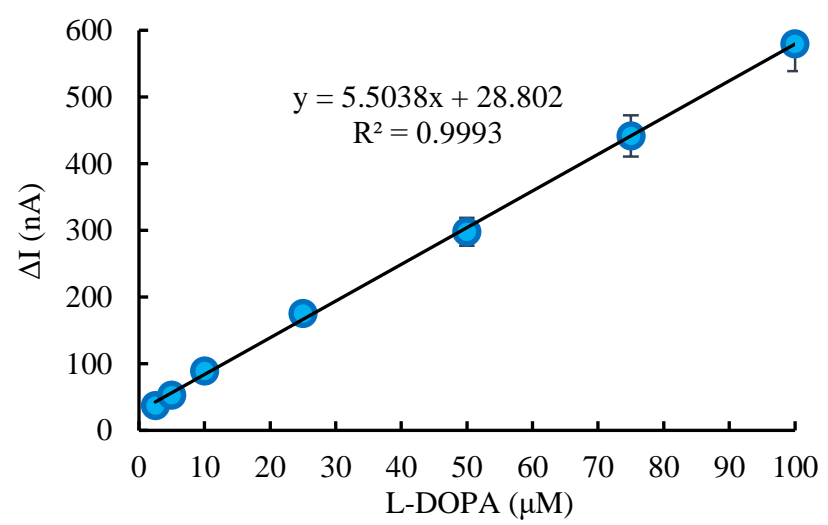

Fig. 7. The calibration curve of $C$. nebularis tissue homogenatebased biosensor.

The LOD value of the proposed biosensor obtained from data of the calibration curve was determined as 0.76 $\mu \mathrm{M}$ for L-DOPA. Moreover, the slope of the calibration curve representing the sensitivity of the L-DOPA biosensor was also determined as $5.5038 \mathrm{nA} \mu \mathrm{M}^{-1}$.

Correlations between L-DOPA concentrations and total charge values were also investigated. For this purpose, a calibration curve was plotted by using total charge value measured at $800 \mathrm{~s}$ by changing L-DOPA concentrations using $25 \mu \mathrm{M}, 50 \mu \mathrm{M}, 75 \mu \mathrm{M}$ and $100 \mu \mathrm{M}$. The LOD value was also calculated for this detection method by using the calibration curve shown in Fig. 8 .

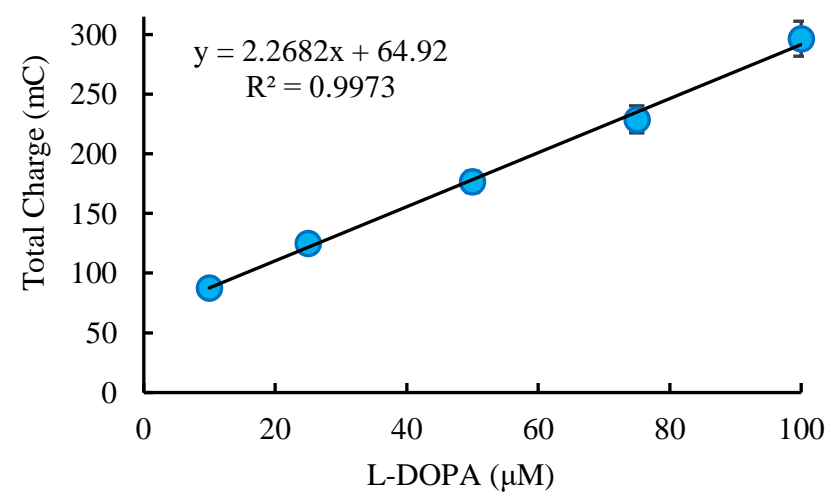

Fig. 8. Calibration curve of the present biosensor for L-DOPA plotted by using total charge values.
Analytical performance of the tissue homogenatebased biosensor, for consecutive additions of L-DOPA, was also examined. The biosensor responses corresponding to different L-DOPA concentrations as 10 $\mu \mathrm{M}, 25 \mu \mathrm{M}, 50 \mu \mathrm{M}, 75 \mu \mathrm{M}, 100 \mu \mathrm{M}, 150 \mu \mathrm{M}$ and 200 $\mu \mathrm{M}$ were shown in Fig. 9. By using these responses, a calibration curve shown in Fig. 10 was plotted between LDOPA concentrations and cumulative $\Delta \mathrm{I}$ values, which were calculated by using the differences between the baseline current value at $100 \mathrm{~s}$ and the current value (I) measured every $600 \mathrm{~s}$ after each L-DOPA addition.

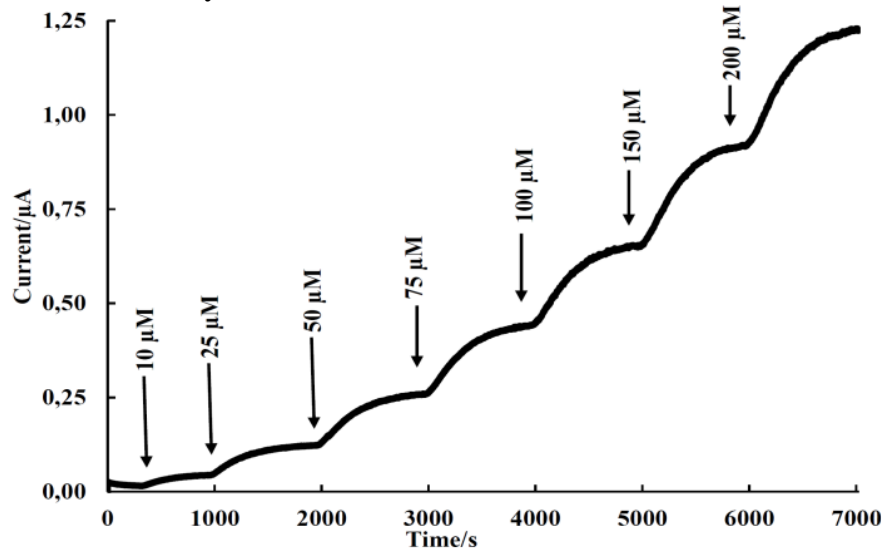

Fig. 9. Biosensor responses for consecutive addition of L-DOPA at different concentrations.

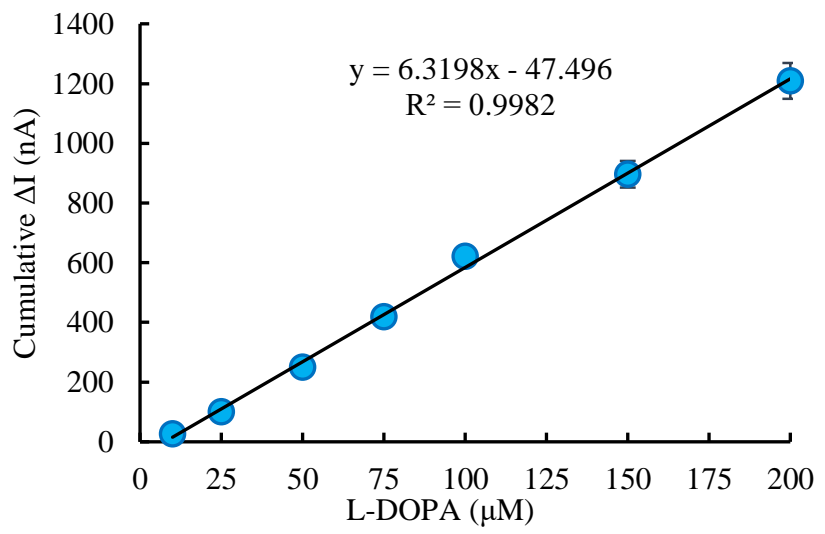

Fig. 10. Calibration curve of the present biosensor plotted by evaluating data from Fig. 9.

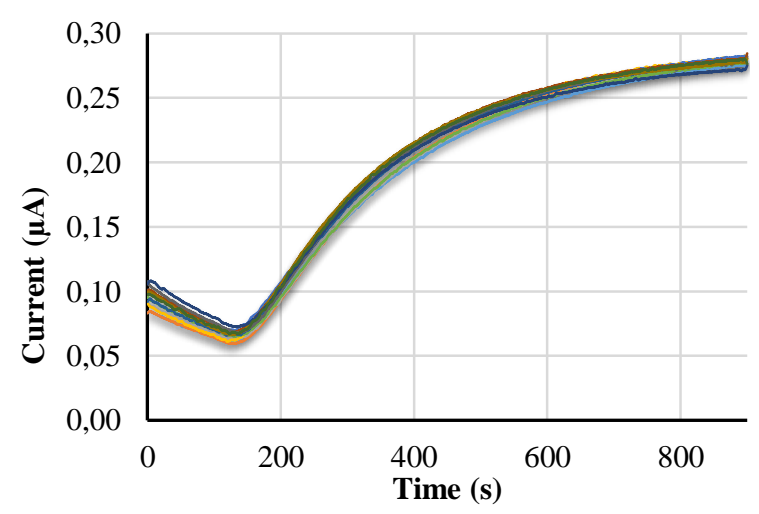

Fig. 11. Biosensor responses for 12 multiple separate measurements for $50.0 \mu \mathrm{M}$ L-DOPA. 


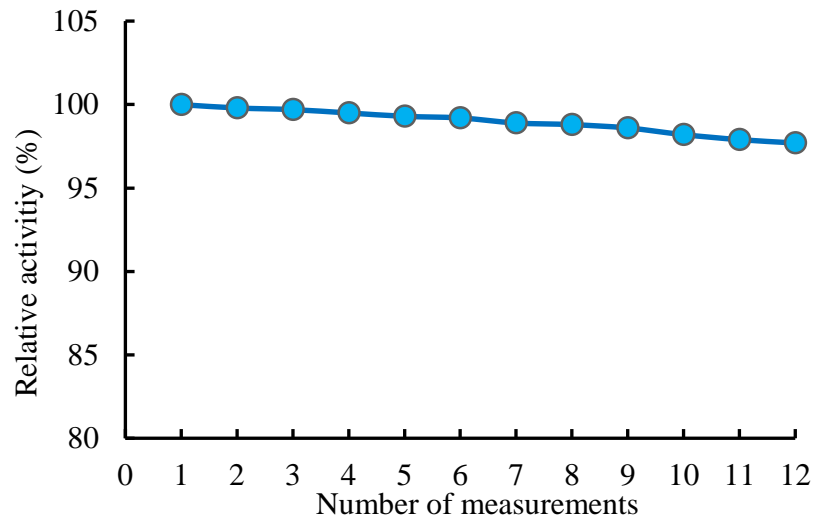

Fig. 12. Operational stability of the biosensor.

\section{Repeatability and operational stability of the biosensor}

Repeatability referring to accuracy, precision and standard error is a crucial parameter for biosensor systems. For evaluation of the repeatability parameters, $\Delta \mathrm{I}$ values measured for 16 separate addition of L-DOPA at $50.0 \mu \mathrm{M}$, were replaced as " $\mathrm{y}$ " in the equation of calibration curve. The mean value, standard deviation and coefficient of variation of the biosensor were determined as $50.01 \mu \mathrm{M}, \pm 0.41 \mu \mathrm{M}$ and $0.82 \%(\mathrm{n}=16)$, respectively.

Operational stability that represents the durability of the biosensor to multiple measurements were also studied. For this purpose, 12 separate measurements without regeneration for $50.0 \mu \mathrm{M}$ L-DOPA were carried out. The biosensor responses and calculated relative activity values for each measurement were shown in Figs 11 and 12, respectively. As can be seen in the figures, the tissue homogenate-based biosensor had good stability for multiple measurements with reasonable precision.
Application to artificial human plasma and urine samples

The monitoring of L-DOPA drugs in urine and plasma has reasonable importance for patients with Parkinson's disease, who are treated with L-DOPA drugs. Evaluation of the analytical performance of the tissue homogenate-based biosensor in physiological fluids is a crucial parameter representing the potential utility of the biosensor in clinical diagnosis. Thus, the analytical performance of the present biosensor was tested in artificial plasma and urine samples. Moreover, the proposed biosensor was examined for the detection of L-DOPA amounts in commercial drugs named Dopalevo $^{\circledR}$ and Madopar ${ }^{\circledR}$. The dissolving of L-DOPA and drugs as well as all of the measurements were carried out by using artificial plasma and urine instead of PBS. By using the reagent L-DOPA, calibration curves with a detection range between $10-200 \mu \mathrm{M}$ were plotted for each electrolyte solution including PBS, artificial plasma and urine. $\mathrm{R}^{2}$ value and LOD values of these calibration curves were calculated as $0.9990,0.9984,0.9986$ and $2.05 \mu \mathrm{M}$, $2.63 \mu \mathrm{M}, 2.46 \mu \mathrm{M}$, respectively. In order to determine the concentrations of commercial drugs by using the proposed biosensor, $500 \mu \mathrm{L}$ of drug solutions were spiked into the reaction cell containing artificial plasma or urine. Concentrations of drug solutions were not curvaceously calculated, owing to the dissociation issue of drug tablets. Thus, a spectrophotometric method was employed to determine the exact concentration of the drug solutions. Hence, drug solutions were diluted with PBS, artificial plasma or urine by evaluating the concentrations detected via spectrophotometry. The biosensor responses and spectrophotometric analyzes were compared in Table 1.

Table 1. The analytical performance of the tissue homogenate-based biosensor in artificial plasma and urine $(n=3)$.

\begin{tabular}{|c|c|c|c|c|}
\hline Spiked Samples & $\begin{array}{l}\text { L-DOPA measured by } \\
\text { spectrophotometer }(\mu \mathrm{M})\end{array}$ & $\begin{array}{l}\text { L-DOPA measured by present biosensor } \\
(\mu \mathrm{M})(\mathrm{n}=3)\end{array}$ & Recovery (\%) & $\operatorname{Bias}(\%)$ \\
\hline $\begin{array}{l}\text { L-DOPA in } \\
\text { artificial plasma }\end{array}$ & 65.11 & $65.91 \pm 0.53$ & 101.22 & 1.22 \\
\hline $\begin{array}{l}\text { L-DOPA in } \\
\text { artificial urine }\end{array}$ & 65.25 & $67.02 \pm 0.51$ & 102.71 & 2.71 \\
\hline $\begin{array}{l}\text { Dopalevo }^{\circledR} \text { in } \\
\text { artificial plasma }\end{array}$ & 92.91 & $95.23 \pm 0.86$ & 102.50 & 2.50 \\
\hline $\begin{array}{l}\text { Dopalevo }^{\circledR} \text { in } \\
\text { artificial urine }\end{array}$ & 141.56 & $146.37 \pm 1.39$ & 103.41 & 3.41 \\
\hline $\begin{array}{l}\text { Dopalevo }{ }^{\circledR} \text { in } \\
\text { PBS }\end{array}$ & 30.09 & $30.38 \pm 0.28$ & 100.98 & 0.98 \\
\hline $\begin{array}{l}\text { Madopar }^{\circledR} \text { in } \\
\text { artificial plasma }\end{array}$ & 91.43 & $94.04 \pm 0.75$ & 102.86 & 2.86 \\
\hline $\begin{array}{l}\text { Madopar }^{\circledR} \text { in } \\
\text { artificial urine }\end{array}$ & 144.32 & $149.70 \pm 1.45$ & 103.73 & 3.73 \\
\hline $\begin{array}{l}\text { Madopar }{ }^{\circledR} \text { in } \\
\text { PBS }\end{array}$ & 56.15 & $56.73 \pm 0.46$ & 101.03 & 1.03 \\
\hline
\end{tabular}




\section{Discussion}

It was reported that some other mushrooms such as Agaricus bisporus (J.E. Lange) Imbach, Coprinus comatus (O.F. Müller) Persoon, Ganoderma tsugae (Murrill), Lentinellus ursinus (Fries) Kühner, Russula delica (Fries) and Trametes versicolor ( $\mathrm{L}$ Linnaeus) Lloyd have protein concentrations as $0.509 \mathrm{mg} / \mathrm{mL}, 0.456$ $\mathrm{mg} / \mathrm{mL}, 0.316 \mathrm{mg} / \mathrm{mL}, 0.409 \mathrm{mg} / \mathrm{mL}, 0.456 \mathrm{mg} / \mathrm{mL}$ and $0.409 \mathrm{mg} / \mathrm{mL}$, respectively (Pandey \& Budhathoki 2007) similar to Clitocybe nebularis, which was used in the present study. Baltierra-Trejo et al. (2015) explained in detail and emphasized that there were a lot of identified inconsistencies in values, units and calculation formulas of the laccase activity in the literature. Hence, proper comparisons of laccase activities determined by the ABTS method could not be accomplished.

It is clearly seen in Fig. 2 that, since the concentration of the gelatine could affect the transfer of oxygen and transportation of L-DOPA to the electrode surface, biosensor signals were decreased by increasing gelatine concentrations. Even though the biosensor containing 1.0 $\mathrm{mg} / \mathrm{mL}$ gelatine had the highest signals, the linearity of this biosensor was worse than the biosensor that contained $2.5 \mathrm{mg} / \mathrm{mL}$ gelatine. It was observed that rigidity and thickness of the gelatine layer could not be stable in the case of $1.0 \mathrm{mg} / \mathrm{mL}$ gelatine concentration. Hence, probable desertion of tissue from electrode surface to reaction media could occur. Since the biosensor containing $2.5 \mathrm{mg} / \mathrm{mL}$ gelatine had the best linearity and stability, $2.5 \mathrm{mg} / \mathrm{mL}$ was selected as the optimum concentration for gelatine.

Increased $C$. nebularis tissue was expected to cause more L-DOPA conversion that increased responses of the biosensor. However, as it is seen in Fig. 3, the highest signals for L-DOPA detection were obtained from the biosensor prepared by using $50 \mathrm{mg}$ tissue. This could be a result of the homogenization process applied since homogenization by utilizing a Potter-Elvehjem homogenizer consisted of a small volume and short time process, an increase in tissue amount brought about the problems including dispersion, squeezing and adhesion of tissue in the homogenizer. It was observed that in the case of tissue homogenates containing $200 \mathrm{mg}$ and $400 \mathrm{mg}$ tissue could not be properly smashed, dispersed and squeezed in the homogenizer. Hence, the yield of tissue homogenization, as well as tissue amount coalescing with carbon paste was decreased. Although the biosensor prepared with $50 \mathrm{mg}$ of tissue had the highest signals, it had the lowest $\mathrm{R}^{2}$ value responding to the linearity of the calibration curve. Thus, considering all results in terms of linearity and biosensor response, $100 \mathrm{mg}$ tissue was selected as the optimum tissue amount for homogenization.

Since carbon paste had a hydrophobic composition without tissue homogenate, an increase in the volume of tissue homogenate could cause a problem for homogenous dispersion of mushroom tissue into the depth of the carbon paste. Hence, the lowest biosensor responses could be obtained from the biosensor fabricated by using $60 \mu \mathrm{L}$ of tissue homogenate, although its linearity was higher than the other two biosensors. Additionally, in the preparation of carbon paste, when mushroom tissue homogenate volume was higher than $30 \mu \mathrm{L}$, aggregate formation on the plate was observed. In case that the volume of tissue homogenate was $15 \mu \mathrm{L}$, although a wellbuilt coalescing between tissue and carbon paste occurred, the enzymatic conversion of L-DOPA was inadequate for higher signals. As seen in Fig. 4, the biosensor fabricated by using $30 \mu \mathrm{L}$ of tissue homogenate had better linearity and higher signal rate than the other biosensors. Thus, the optimum volume of $C$. nebularis tissue homogenate was determined as $30 \mu \mathrm{L}$ for L-DOPA detection.

In tissue homogenate, many types of enzymes such as laccase, tyrosinase or polyphenol oxidase could convert L-DOPA to dopaquinone. Thus, as seen in Fig. 5 , the proposed tissue homogenate-based biosensor worked well by the activity up to $80 \%$ and reached to optimum value at $\mathrm{pH} 7.5$. These results were expected results for a tissue homogenate-based biosensor since similar plots were obtained by other tissue-based biosensors (Leite et al. 2003a, Sezgintürk et al. 2005, Felix et al. 2006, Liu et al. 2010, Narang et al. 2011, Rahimi-Mohseni et al. 2018, Sandeep et al. 2018). Moreover, the optimum $\mathrm{pH}$ depended on both the presence of the catalyzing enzymes and the solubility of the substrate at these $\mathrm{pH}$ values. In this case, the solubility of L-DOPA increased slowly at around neutral $\mathrm{pH}$, owing to its charged groups (Ali et al. 2014). Furthermore, these properly-working $\mathrm{pH}$ scales of the proposed biosensor facilitated the detection of L-DOPA in human samples at different $\mathrm{pH}$ values such as plasma at $\mathrm{pH} 7.4$ and urine at $\mathrm{pH}$ 6.0. Finally, since the isoelectric point of L-DOPA is 5.2, biosensor responses at pH 5.0 and $\mathrm{pH} 5.5$ might be decreased.

In optimum temperature experiments, although a tendency of increase in the activity was observed at higher degrees, $35^{\circ} \mathrm{C}$ was selected as the optimum temperature due to the low stability of gelatine at temperatures higher than $35^{\circ} \mathrm{C}$ (Odaci et al. 2004, Topçu et al. 2004, Sezgintürk \& Dinçkaya 2005, Ozcan \& Sagiroglu 2010).

As seen in Fig. 7, the calibration curve had good $\mathrm{R}^{2}$ representing linearity and a wide detection range, from 2.5 $\mu \mathrm{M}$ to $100 \mu \mathrm{M}$, which includes the concentrations of LDOPA levels in plasma and urine for both healthy and people using L-DOPA drugs determined before (Baranowska \& Plonka 2008).

Since an increase in the current caused enhancing the migration of electrons to the electrode surface, the signal was in a tendency of increasing by the addition of LDOPA. The LOD value of this method evaluated by using the same calculation method discussed above was determined as $2.73 \mu \mathrm{M}$. The linearity as $\mathrm{R}^{2}$ value and the sensitivity of this curve along with LOD value showed that total charge could be promisingly utilized for the quantification of target molecules. 
Table 2. Comparison of the L-DOPA biosensors on literature.

\begin{tabular}{|c|c|c|c|c|c|}
\hline Biocomponent & $\begin{array}{l}\text { Analytical } \\
\text { Method }\end{array}$ & $\begin{array}{c}\text { Detection } \\
\text { Range }(\mu \mathrm{M})\end{array}$ & $\begin{array}{l}\text { Linearity } \\
\left(\mathbf{R}^{2}\right)\end{array}$ & $\begin{array}{l}\text { LOD } \\
(\mu \mathrm{M})\end{array}$ & Ref. \\
\hline Isolated laccase from Pleurotus ostreatus & $\begin{array}{c}\text { Differential } \\
\text { Pulse } \\
\text { Voltammetry }\end{array}$ & $6.7-70$ & N/A & 0.24 & (Leite et al. 2003b) \\
\hline $\begin{array}{l}\text { Extracted tyrosinase from Amorphophallus } \\
\text { campanulatus }\end{array}$ & Optical & $10-1000$ & 0.99 & 3.0 & (Saini et al. 2014) \\
\hline Isolated laccase from Trametes versicolor & Amperometry & $2.0-20$ & 0.9898 & N/A & (Timur et al. 2004) \\
\hline Commercial laccase from Cerrena unicolor & Amperometry & $1-40$ & 0.999 & 0.49 & (Jarosz-Wilkołazka et al. 2005) \\
\hline Purified laccase from Trametes versicolor & Amperometry & $1-20$ & 0.9996 & 0.65 & (Haghighi et al. 2003) \\
\hline Commercial tyrosinase from mushroom & Amperometry & $0.8-22$ & 0.9907 & 2.5 & (Brunetti et al. 2014) \\
\hline $\begin{array}{l}\text { Extracted polyphenol oxidase from } \\
\text { Manilkara Zapota }\end{array}$ & $\begin{array}{l}\text { Differential Pulse } \\
\text { Voltammetry }\end{array}$ & $2-140$ & 0.933 & 1.85 & (Sandeep et al. 2018) \\
\hline $\begin{array}{l}\text { Extracted polyphenol oxidase from banana } \\
\text { fruit }\end{array}$ & Amperometry & $0.2-400$ & 0.994 & 0.2 & (Narang et al. 2011) \\
\hline Tissue homogenate of Clitocybe nebularis & Amperometry & $2.5-100$ & 0.9993 & 0.76 & Present study \\
\hline
\end{tabular}

In Table 2, the present $C$. nebularis tissue-based biosensor was compared to other biosensors for L-DOPA detection in parameters including linear range, LOD and linearity.

Although the biosensors (Haghighi et al. 2003, Leite et al. 2003b, Jarosz-Wilkołazka et al. 2005) have lower LOD values than the proposed biosensor with similar linearity, the detection ranges of these biosensors were narrower than our biosensor had. Even though the biosensors (Saini et al. 2014, Sandeep et al. 2018) could detect L-DOPA with a wide range, the present biosensor showed a better correlation and had a lower LOD value. Moreover, the linearity, LOD value and detection range of the present biosensor were reasonably preferable to the biosensors (Timur et al. 2004, Brunetti et al. 2014). The biosensor of Narang et al. (2011) has better results than our work, however, it had a more complicated construction process and more expensive materials for the fabrication of the biosensor. Since the transition of LDOPA and oxygen was a usual challenge for tissue homogenate-based biosensors, all of these L-DOPA biosensors having purified, commercial or extracted enzymes had better response time than the present work. However, the response time of the present biosensor as $600 \mathrm{~s}$ was similar to other tissue homogenate-based biosensors in the literature (Sezgintürk \& Dinçkaya 2003, 2004, Silva et al. 2014). Furthermore, as seen in Table 2, although other biosensors employed different forms of enzymes such as isolated, purified, commercial or extracted enzymes, their analytical performances were not much better than our simply-constructed tissue homogenate-based biosensor. By the use of tissue homogenate-based biosensors, time-consuming and complex processes such as enzyme extraction, isolation and purification are not required. Finally, proposed $C$. nebularis tissue homogenate-based biosensor not only detected L-DOPA molecule consistently, sensitively and accurately but also offered an easy-to-apply and inexpensive alternative to those reported in literature.

The calibration curve shown in Fig. 10 facilitated the monitoring of higher L-DOPA levels with good linearity and sensitivity. Furthermore, the performance of the proposed biosensor in consecutive L-DOPA additions showed that it could work properly with flow-injection systems.

It can be deduced from the results of repeatability experiments that the present biosensor which had better values than the other biosensors (Timur et al. 2004, Chawla et al. 2010), could detect L-DOPA precisely and reliably.

It is obviously seen in Table 1 that the proposed biosensor had a good performance at analyses of spiked LDOPA and commercial drugs in all of the measurement media. Since the artificial urine containing uric acid and sulfates might interfere with the signal, a little increase in biosensor responses caused a tiny deviation for L-DOPA detection in artificial urine. Moreover, some constituents of commercial L-DOPA drugs could interfere with the signal. 


\section{Conclusion}

A simply constructed and inexpensive C. nebularis tissue homogenate-based amperometric biosensor was developed for accurate and sensitive detection of LDOPA. The proposed biosensor would be the first biosensor, which contained a mushroom of Clitocybe sp. in the literature. In the fabrication of the biosensor, $30 \mu \mathrm{L}$ of tissue homogenate was immobilized into the cavity of the carbon-paste electrode by using $120 \mathrm{mg}$ of graphite powder, $140 \mu \mathrm{L}(60 \mathrm{mg})$ of mineral oil, $2.5 \mathrm{mg} / \mathrm{mL}$ of gelatine and $2.5 \%$ of glutaraldehyde. The present biosensor detected L-DOPA with a linear dynamic range at $2.5-100 \mu \mathrm{M}$ and LOD value as $0.76 \mu \mathrm{M}$, as well as standard deviation as $\pm 0.41 \mu \mathrm{M}$ and coefficient of variation as $0.82 \%(\mathrm{n}=16)$. It can be noticed from the results that the proposed biosensor showed good performance in terms of the means of precision, linearity

\section{References}

1. Ali, M., Barman, K., Jasimuddin, S. \& Ghosh, S.K. 2014. Fluid interface-mediated nanoparticle membrane as an electrochemical sensor. RSC Advances, 4(106): 6140461408. https://doi.org/10.1039/c4ra12149j

2. Ayna, A. \& Akyilmaz, E. 2018. Development of a biosensor based on myrtle (Myrtus communis L.) tissue homogenate for voltammetric determination of epinephrine. Hacettepe Journal of Biology and Chemistry, 46(3): 321-328. https://doi.org/10.15671/HJBC.2018.240

3. Baltierra-Trejo, E., Márquez-Benavides, L. \& SánchezYáñez, J.M. 2015. Inconsistencies and ambiguities in calculating enzyme activity: The case of laccase. Journal of Microbiological Methods, 119: 126-131. https://doi.org/10.1016/j.mimet.2015.10.007

4. Baranowska, I. \& Plonka, J. 2008. Determination of levodopa and biogenic amines in urine samples using highperformance liquid chromatography. Journal of Chromatographic Science, 46(1): 30-34. https://doi.org/10.1093/chromsci/46.1.30

5. Bradford, M.M. 1976. A rapid and sensitive method for the quantitation of microgram quantities of protein utilizing the principle of protein-dye binding. Analytical Biochemistry, 72(1-2): 248-254. https://doi.org/10.1016/0003-2697(76)90527-3

6. Breton, F., Euzet, P., Piletsky, S.A., Giardi, M.T. \& Rouillon, R. 2006. Integration of photosynthetic biosensor with molecularly imprinted polymer-based solid phase extraction cartridge. Analytica Chimica Acta, 569(12): 5057. https://doi.org/10.1016/j.aca.2006.03.086

7. Brunetti, B., Valdés-Ramírez, G., Litvan, I. \& Wang, J. 2014. A disposable electrochemical biosensor for L-DOPA determination in undiluted human serum. Electrochemistry Communications, 48: 28-31.

https://doi.org/10.1016/j.elecom.2014.08.007

8. Camargo, J.R., Andreotti, I.A.A., Kalinke, C., Henrique, J.M., Bonacin, J.A. \& Janegitz, B.C. 2020. Waterproof paper as a new substrate to construct a disposable sensor for the electrochemical determination of paracetamol and melatonin. Talanta, 208: 120458. https://doi.org/10.1016/j.talanta.2019.120458 and sensitivity for L-DOPA in PBS. Moreover, the determination of L-DOPA spiked as both drug and chemical into artificial biological fluids was accomplished with a decent recovery rate. These results indicate that the biosensor could be utilized for monitoring of L-DOPA levels of patients suffering from Parkinson's disease. Finally, the laccase activity of $C$. nebularis was observed for the first time by using the spectrophotometric ABTS method.

Ethics Committee Approval: Since the article does not contain any studies with human or animal subject, its approval to the ethics committee was not required.

Conflict of Interest: The author have no conflicts of interest to declare.

Funding: The author declared that this study has received no financial support.

9. César, I.C., Byrro, R.M.D., Santana e Silva Cardoso, F.F., Mundim, I.M., Souza Teixeira, L., Gomes, S.A., Bonfim, R.R. \& Pianetti, G.A. 2011. Development and validation of a high-performance liquid chromatography-electrospray ionization-MS/MS method for the simultaneous quantitation of levodopa and carbidopa in human plasma. Journal of Mass Spectrometry, 46(9): 943-948. https://doi.org/10.1002/jms.1973

10. Chawla, S., Narang, J. \& Pundir, C.S. 2010. An amperometric polyphenol biosensor based on polyvinyl chloride membrane. Analytical Methods, 2(8): 1106-1111. https://doi.org/10.1039/c0ay00165a

11. Chou, Y.C., Shih, C.I., Chiang, C.C., Hsu, C.H. \& Yeh, Y.C. 2019. Reagent-free DOPA-dioxygenase colorimetric biosensor for selective detection of L-DOPA. Sensors and Actuators, B: Chemical, 297: 126717. https://doi.org/10.1016/j.snb.2019.126717

12. da Silva, E.T.S.G., Souto, D.E.P., Barragan, J.T.C., de F. Giarola, J., de Moraes, A.C.M. \& Kubota, L.T. 2017. Electrochemical biosensors in point-of-care devices: recent advances and future trends. ChemElectroChem, 4(4): 778794. https://doi.org/10.1002/CELC.201600758

13. Davletshina, R., Ivanov, A., Shamagsumova, R., Evtugyn, V. \& Evtugyn, G. 2020. Electrochemical biosensor based on polyelectrolyte complexes with dendrimer for the determination of reversible inhibitors of acetylcholinesterase. Analytical Letters, 1-20. https://doi.org/10.1080/00032719.2020.1821700

14. Faria, H.A.M. \& Zucolotto, V. 2019. Label-free electrochemical DNA biosensor for zika virus identification. Biosensors and Bioelectronics, 131: 149155. https://doi.org/10.1016/j.bios.2019.02.018

15. Felix, F.S., Yamashita, M. \& Angnes, L. 2006. Epinephrine quantification in pharmaceutical formulations utilizing plant tissue biosensors. Biosensors and Bioelectronics, 21(12): 2283-2289. https://doi.org/10.1016/j.bios.2005.10.025

16. Fernandes, S.C., de Oliveira, I.R.W.Z. \& Vieira, I.C. 2007. A green bean homogenate immobilized on chemically crosslinked chitin for determination of caffeic acid in white 
wine. Enzyme and Microbial Technology, 40(4): 661-668. https://doi.org/10.1016/j.enzmictec.2006.05.023

17. Gao, G., Fang, D., Yu, Y., Wu, L., Wang, Y. \& Zhi, J. 2017. A double-mediator based whole cell electrochemical biosensor for acute biotoxicity assessment of wastewater. Talanta, 167: 208-216.

https://doi.org/10.1016/j.talanta.2017.01.081

18. Haghighi, B., Gorton, L., Ruzgas, T. \& Jönsson, L.J. 2003. Characterization of graphite electrodes modified with laccase from Trametes versicolor and their use for bioelectrochemical monitoring of phenolic compounds in flow injection analysis. Analytica Chimica Acta, 487(1): 314. https://doi.org/10.1016/S0003-2670(03)00077-1

19. Hormozi-Nezhad, M.R., Moslehipour, A. \& Bigdeli, A. 2017. Simple and rapid detection of L-dopa based on in situ formation of polylevodopa nanoparticles. Sensors and Actuators, B: Chemical, 243: 715-720. https://doi.org/10.1016/j.snb.2016.12.059

20. Jarosz-Wilkołazka, A., Ruzgas, T. \& Gorton, L. 2005. Amperometric detection of mono- and diphenols at Cerrena unicolor laccase-modified graphite electrode: Correlation between sensitivity and substrate structure. Talanta, 66(5): 1219-1224. https://doi.org/10.1016/j.talanta.2005.01.026

21. Karpińska, J., Smyk, J. \& Wołyniec, E. 2005. A spectroscopic study on applicability of spectral analysis for simultaneous quantification of 1-dopa, benserazide and ascorbic acid in batch and flow systems. Spectrochimica Acta - Part A: Molecular and Biomolecular Spectroscopy, 62(1-3): 213-220. https://doi.org/10.1016/j.saa.2004.12.029

22. Kosanić, M., Petrović, N. \& Stanojković, T. 2020. Bioactive properties of Clitocybe geotropa and Clitocybe nebularis. Journal of Food Measurement and Characterization, 14(2): 1046-1053. https://doi.org/10.1007/s11694-019-00354-7

23. Kozan, J.V.B., Silva, R.P., Serrano, S.H.P., Lima, A.W.O. \& Angnes, L. 2007. Biosensing hydrogen peroxide utilizing carbon paste electrodes containing peroxidases naturally immobilized on coconut (Cocus nucifera L.) fibers. Analytica Chimica Acta, 591(2): 200-207. https://doi.org/10.1016/j.aca.2007.03.058

24. Kumarathasan, P. \& Vincent, R. 2003. New approach to the simultaneous analysis of catecholamines and tyrosines in biological fluids. Journal of Chromatography A, 987(1-2): 349-358. https://doi.org/10.1016/S0021-9673(02)01598-4

25. Leite, O.D., Lupetti, K.O., Fatibello-Filho, O., Vieira, I.C. \& Barbosa, A. de M. 2003a. Synergic effect studies of the bi-enzymatic system laccaseperoxidase in a voltammetric biosensor for catecholamines. Talanta, 59(5): 889-896. https://doi.org/10.1016/S0039-9140(02)00650-1

26. Leite, O.D., Fatibello-Filho, O. \& Barbosa, A.D.M. 2003 b. Determination of catecholamines in pharmaceutical formulations using a biosensor modified with a crude extract of fungi laccase (Pleurotus ostreatus). Journal of the Brazilian Chemical Society, 14(2): 297-303. https://doi.org/10.1590/S0103-50532003000200018

27. Li, Y., Han, J., Jiang, L., Li, F., Li, K. \& Dong, Y. 2015. A glucose biosensor based on 1mmobilization of glucose oxidase on platinum nanoparticle doped santa barbara amorphous material-15. Analytical Letters, 48(7): 1139 1149. https://doi.org/10.1080/00032719.2014.974056

28. Liu, Q., Ye, W., Yu, H., Hu, N., Du, L., Wang, P. \& Yang, M. 2010. Olfactory mucosa tissue-based biosensor: A bioelectronic nose with receptor cells in intact olfactory epithelium. Sensors and Actuators, B: Chemical, 146(2): 527-533. https://doi.org/10.1016/j.snb.2009.12.032

29. Luis, P., Walther, G., Kellner, H., Martin, F. \& Buscot, F. 2004. Diversity of laccase genes from basidiomycetes in a forest soil. Soil Biology and Biochemistry, 36(7): 1025 1036. https://doi.org/10.1016/j.soilbio.2004.02.017

30. Narang, J., Chauhan, N., Singh, A. \& Pundir, C.S. 2011. A nylon membrane based amperometric biosensor for polyphenol determination. Journal of Molecular Catalysis B: Enzymatic, 72(3-4): 276-281. https://doi.org/10.1016/j.molcatb.2011.06.016

31. Nomngongo, P.N., Ngila, J.C., Nyamori, V.O., Songa, E.A. \& Iwuoha, E.I. 2011. Determination of Selected Heavy Metals Using Amperometric Horseradish Peroxidase (HRP) Inhibition Biosensor. Analytical Letters, 44(11): 2031-2046. https://doi.org/10.1080/00032719.2010.539738

32. Odaci, D., Timur, S. \& Telefoncu, A. 2004. Immobilized jerusalem artichoke (Helianthus tuberosus) tissue electrode for phenol detection. Artificial Cells, Blood Substitutes, and Biotechnology, 32(2): 315-323. https://doi.org/10.1081/BIO-120037836

33. Ori, Z., Kiss, A., Ciucu, A.A., Mihailciuc, C., Stefanescu, C.D., Nagy, L. \& Nagy, G. 2014. Sensitivity enhancement of a "bananatrode" biosensor for dopamine based on SECM studies inside its reaction layer. Sensors and Actuators, B: Chemical, 190: 149-156.

https://doi.org/10.1016/j.snb.2013.08.063

34. Ozcan, H.M. \& Aydin, T. 2016. A new PANI biosensor based on catalase for cyanide determination. Artificial Cells, Nanomedicine and Biotechnology, 44(2): 664-671. https://doi.org/10.3109/21691401.2014.978979

35. Ozcan, H.M. \& Sagiroglu, A. 2010. A novel amperometric biosensor based on banana peel (Musa cavendish) tissue homogenate for determination of phenolic compounds. Artificial Cells, Blood Substitutes, and Biotechnology, 38(4): 208-214. https://doi.org/10.3109/10731191003776744

36. Ozcan, H.M. \& Sagiroglu, A. 2014. Fresh broad (Vicia $f a b a)$ tissue homogenate-based biosensor for determination of phenolic compounds. Artificial Cells, Nanomedicine and Biotechnology, 42(4): 256-261. https://doi.org/10.3109/21691401.2013.764313

37. Pandey, N. \& Budhathoki, U. 2007. Protein determination through bradford's method of nepalese mushroom. Scientific World, 5(5): 85-88. https://doi.org/10.3126/sw.v5i5.2662

38. Pontius, K., Semenova, D., Silina, Y.E., Gernaey, K. V. \& Junicke, H. 2020. Automated electrochemical glucose biosensor platform as an efficient tool toward on-line fermentation monitoring: novel application approaches and 1nsights. Frontiers in Bioengineering and Biotechnology, 8: 436. https://doi.org/10.3389/fbioe.2020.00436

39. Rahimi-Mohseni, M., Raoof, J.B., Ojani, R., Aghajanzadeh, T.A. \& Bagheri Hashkavayi, A. 2018. Development of a new paper based nano-biosensor using the co-catalytic effect of tyrosinase from banana peel tissue 
(Musa cavendish) and functionalized silica nanoparticles for voltammetric determination of L-tyrosine. International Journal of Biological Macromolecules, 113: 648-654. https://doi.org/10.1016/j.ijbiomac.2018.02.060

40. Rasmussen, C.D., Andersen, J.E.T. \& ZachauChristiansen, B. 2007. Improved performance of the potentiometric biosensor for the determination of creatinine. Analytical Letters, 40(1): 39-52.

https://doi.org/10.1080/00032710600952341

41. Sagiroglu, A., Paluzar, H., Ozcan, H.M., Okten, S. \& Sen, B. 2011. A novel biosensor based on lactobacillus acidophilus for determination of phenolic compounds in milk products and wastewater. Preparative Biochemistry and Biotechnology, 41(4): 321-336. https://doi.org/10.1080/10826068.2010.540607

42. Saini, A.S., Kumar, J. \& Melo, J.S. 2014. Microplate based optical biosensor for 1-Dopa using tyrosinase from Amorphophallus campanulatus. Analytica Chimica Acta, 849: 50-56. https://doi.org/10.1016/j.aca.2014.08.016

43. Sandeep, S., Santhosh, A.S., Swamy, N.K., Suresh, G.S., Melo, J.S. \& Nithin, K.S. 2018. Electrochemical detection of L-dopa using crude polyphenol oxidase enzyme immobilized on electrochemically reduced RGO-Ag nanocomposite modified graphite electrode. Materials Science and Engineering B: Solid-State Materials for Advanced Technology, 232-235: 15-21. https://doi.org/10.1016/j.mseb.2018.10.014

44. Sanders, C.A., Rodriguez, M. \& Greenbaum, E. 2001. Stand-off tissue-based biosensors for the detection of chemical warfare agents using photosynthetic fluorescence induction. Biosensors and Bioelectronics, 16(7-8): 439446. https://doi.org/10.1016/S0956-5663(01)00158-0

45. Sarigul, N., Korkmaz, F. \& Kurultak, İ. 2019. A new artificial urine protocol to better imitate human urine. Scientific Reports, 9: 20159. https://doi.org/10.1038/s41598-019-56693-4

46. Sayikli Şimşek, Ç., Nur Sonuç Karaboğa, M. \& Sezgintürk, M.K. 2015. A new immobilization procedure for development of an electrochemical immunosensor for parathyroid hormone detection based on gold electrodes modified with 6-mercaptohexanol and silane. Talanta, 144: 210-218. https://doi.org/10.1016/j.talanta.2015.06.010

47. Sezgintürk, M.K. \& Dinçkaya, E. 2003. A novel amperometric biosensor based on spinach (Spinacia oleracea) tissue homogenate for urinary oxalate determination. Talanta, 59(3): 545-551. https://doi.org/10.1016/S0039-9140(02)00539-8

48. Sezgintürk, M.K. \& Dinçkaya, E. 2004. An amperometric inhibitor biosensor for the determination of reduced glutathione (GSH) without any derivatization in some plants. Biosensors and Bioelectronics, 19(8): 835-841. https://doi.org/10.1016/j.bios.2003.08.012

49. Sezgintürk, M.K. \& Dinçkaya, E. 2005. Direct determination of sulfite in food samples by a biosensor based on plant tissue homogenate. Talanta, 65(4): 9981002. https://doi.org/10.1016/j.talanta.2004.08.037

50. Sezgintürk, M.K. \& Dinçkaya, E. 2012. Sulfite determination by an inhibitor biosensor-based mushroom (Agaricus bisporus) tissue homogenate. Artificial Cells, Blood Substitutes, and Biotechnology, 40(1-2): 38-43. https://doi.org/10.3109/10731199.2011.585614
51. Sezgintürk, M.K., Göktug, T. \& Dinçkaya, E. 2005. Detection of benzoic acid by an amperometric inhibitor biosensor based on mushroom tissue homogenate. Food Technology and Biotechnology, 43(4): 329-334.

52. Shin, K.S. \& Lee, Y.J. 2000. Purification and characterization of a new member of the laccase family from the white-rot basidiomycete Coriolus hirsutus. Archives of Biochemistry and Biophysics, 384(1): 109-115. https://doi.org/10.1006/abbi.2000.2083

53. Silva, L.M.C., De Mello, A.C.C. \& Salgado, A.M. 2014. Phenol determination by an amperométrico biosensor based on lyophilized mushroom (Agaricus bisporus) tissue. Environmental Technology (United Kingdom), 35(8): 10121017. https://doi.org/10.1080/09593330.2013.858755

54. Sun, A., Wambach, T., Venkatesh, A.G. \& Hall, D.A. 2014. A low-cost smartphone-based electrochemical biosensor for point-of-care diagnostics. IEEE 2014 Biomedical Circuits and Systems Conference, BioCAS 2014 . Proceedings, 312-315. https://doi.org/10.1109/BioCAS.2014.6981725

55. Tashkhourian, J., Hormozi-Nezhad, M.R. \& Khodaveisi, J. 2011. Application of silver nanoparticles and principal component-artificial neural network models for simultaneous determination of levodopa and benserazide hydrochloride by a kinetic spectrophotometric method. Spectrochimica Acta - Part A: Molecular and Biomolecular Spectroscopy, 82(1): 25-30. https://doi.org/10.1016/j.saa.2011.06.014

56. Thoppe Rajendran, S., Huszno, K., Dębowski, G., Sotres, J., Ruzgas, T., Boisen, A. \& Zór, K. 2020. Tissue-based biosensor for monitoring the antioxidant effect of orally administered drugs in the intestine. Bioelectrochemistry, 138: 107720. https://doi.org/10.1016/j.bioelechem.2020.107720

57. Timur, S., Pazarloğlu, N., Pilloton, R. \& Telefoncu, A. 2004. Thick film sensors based on laccases from different sources immobilized in polyaniline matrix. Sensors and Actuators, B: Chemical, 97(1): 132-136. https://doi.org/10.1016/j.snb.2003.07.018

58. Topçu, S., Sezgintürk, M.K. \& Dinçkaya, E. 2004. Evaluation of a new biosensor-based mushroom (Agaricus bisporus) tissue homogenate: Investigation of certain phenolic compounds and some inhibitor effects. Biosensors and Bioelectronics, 20(3): 592-597. https://doi.org/10.1016/j.bios.2004.03.011

59. Tuncay, D. \& Yagar, H. 2020. Decolorization of Reactive Blue-19 textile dye by Boletus edulis laccase immobilized onto rice husks. International Journal of Environmental Science and Technology, 17(6): 3177-3188. https://doi.org/10.1007/s13762-020-02641-z

60. Zhang, G.Q., Wang, Y.F., Zhang, X.Q., Ng, T.B. \& Wang, H.X. 2010. Purification and characterization of a novel laccase from the edible mushroom Clitocybe maxima. Process Biochemistry, 45(5): 627-633. https://doi.org/10.1016/j.procbio.2009.12.010

61. Zwirtes de Oliveira, I.R.W., Fernandes, S.C. \& Vieira, I.C. 2006. Development of a biosensor based on gilo peroxidase immobilized on chitosan chemically crosslinked with epichlorohydrin for determination of rutin. Journal of Pharmaceutical and Biomedical Analysis, 41(2): 366-372. https://doi.org/10.1016/j.jpba.2005.12.019 